more, and latterly by a fair stream, but projected with little force. If he should talk during the act the flow stops, and he has to strain to get it to resume. He cennot tell when the stream stops or when it flows save by watching it. A few ounces are left in the bladder after the com. pletion of the act by this method. In the other method he assumes a sitting posture, and passing his finger into the rectum there immediately ensues a full and forcible stream of urine. It generally stops soon after the finger is withdrawn, and is excited by its reintroduction. Neither by this method is he aware from urethral sensations that he voids urine. In this way the bladder can be completely emptied. The power of coitus is still in abeyance. Digestive: Tongue clean; no discomfort after meals and appetite fair. The bowels are very costive, and he has to take castor oil frequently in order to get a liquid motion, otherwise the fæces become hard and lodge in the rectum, whence they have to be displaced with the finger. On passing the finger into the rectum the sphincter is found laxer than natural, yet there is no incontinence.

The diagnosis in this case points to a syphilitic gummatous tumour, situated either in the substance of, or in the sheath and pressing into, the left half of the spinal cord at the upper part of the lumbar enlargement. Latterly the gumma having in all likelihood been absorbed has left the tissues permanently damaged.

(To be concluded.)

\section{ORCHITIS, WITH SLOUGH OF A PORTION OF THE TESTICLE, FOLLOWING TYPHOID FEVER.}

By C. E. HARRISON, M.B. LoND., F.R.C.S., SURGEON, 2ND BATTALION, GRENADIER GUARDS.

Mr. $X$ - having passed through the fatigues and exposure of the recent campaign in Egypt, arrived at Cairo with his battalion on September 17th. On the 27th, having felt unwell for some days previously, he was seized with intense headache, high temperature, and other febrile symptoms, which, after running a somewhat irregular course, developed the characteristic features of typhoid fever. The rose-spots, the character of the dejections, condition of the tongue, enlargement of the spleen, and pulmonary congestion were all marked. On October 27 th he was considered sufficiently convalescent, although still weak, to leave Cairo by river steamer for Alexandria, travelling thence to England in a hospital ship. There was some return of diarrhœa during the voyage home, and on his arrival in England on November lith he was exposed to the cold east wind then prevailing. On the following day his temperature was $99.2^{\circ}$ and there was some looseness of the bowels. On the afternoon of the 16th he was suddenly seized with pain in the right testicle, which became very acute during the night. On the 17th I found the testicle considerably enlarged, with redness and odema of the scrotum. The epididymis was but little affected. There was no gleet or history of urethral discharge, and no local injury conld account for the acute orchitis. Considering his weak state of health, it was deemed unadvisable to abstract blood. Fomentations with poultices and extract of belladonna were applied, and a saline mixture, with an opiate at night, was ordered. On Nov. 18th the patient experienced considerable pain in the testicle, which came on in paroxysms. There was some fulness and tenderness in the line of the spermatic cord. Temperature $1028^{\circ}$. On the 21 st the temperature was $101 \cdot 4^{\circ}$; pulse 96 ; slight shivering. On the 27 th indistinct fluctuation was felt. Sir James Paget, who had seen the patien on the 2lst, approved of an exploration being made with the needle of an hypodermic syringe, but the presence of pus was not detected. This is probably accounted for by the needle having passed into a portion of dead tissue which was subsequently thrown off as a slough. On Dec. 13th the fluctuation was distinct. Two incisions were made, but little pus was evactuated. On the 14th the temperature was $99^{\circ}$. A small portion of slough presented between the edges of the upper wound, and this continued to increase in size, being gradually extruded. Having reached the size of an almond, the slough finally came away at the end of the montb, and the wounds completely healed. At the present time the testicle is considerably diminished in size, but no further trouble has resulted.

To those interested in this rare sequela of typhoid fever, an interesting paper by M. Widal, and a discussion on the subject, will be found in the "Bulletin de la Société Clin. de Paris," $1877-78$, p. 142. M. Dieulafoy here mentions that he has seen a case of suppuration, and that $M$. Chedevergne has reported another. Various causes to account for the complication are here suggested. M. Vallin suggests catarrhal inflammation of the seminiferous ducts; M. Vidal, thrombosis of the spermatic veins; M. Hallopeau, parenchymatous lesion rendering the organ susceptible of injury. In the same volume, p. $229, M$. Sabourin reports a case. In the "Archives Générales de Médecine," 1878, vol. ii., p. 595, M. Hanot reports several cases, one case being almost identical with the subject of the present report. M. Paul Larquier published a thesis in 1882, entitled "L'Orehite dans la Fièvre Typhoide." Dr. Marston in his excellent paper on the fevers of Malta and the Mediterranean in the yeports of the Army Medical Department, 1861, speaks of rheumatic orchitis as occurring after the Mediterranean remittent fever. He mentions one case of suppuration. Dr. Duffey's paper (in the Dublin Journal, 1872, vol. i., p. 97) was referred to in your issue of Dec. 9th. Prof. A. Liebermeister, in Ziemssen's Cyclopædia, vol. i., p. 181, speaks of the complication, but observes, "All the cases that I ever saw ran a very slight course." As to the cause, may not orchitis be closely allied to parotitis, which is also a sequela of typhoid, and may not both be described as an expression of blood-poisoning?

Wellington Barracks.

\section{THE LIGATURE-TIGHTENER.}

\author{
BY JOHN CLAY, M.R.C.S. \&C.,
}

OBSTETRIC SURGEON TO THE QUEEN'S HOSPITAL, BIRMINGHAM.

THE instrument represented in the accompanying woodcut is devised, as its name indicates, for the purpose of tightening and securing a ligature applied to a structure so situated that the fingers cannot be efficiently used to tighten it; or of being applied to a morbid growth, the size of which may require greater constricting power than can be produced with the fingers alone. The ligature recommended is one com. posed of five or six strands of the best white thread, the strands being from fifteen to eighteen inches in length. The ligature is passed twice round the part to be tied, as shown in the woodcut. The ends of the ligature are fastened to the stem of the instrument, which is then worked as an ordinary wire-rope écraseur. If the ligature is properly applied to the part, no second tying of it is required. Ordinary single ligatures may be tightened by the instrument. Wire may be used to constrict a morbid growth, either temporarily or permanently, before removal. The wire is applied singly around the growth, and is crossed before fixing it to the instrument. When sufficient constricting power has been produced, the wire is twisted by making two or three turns of the whole instrument. The instrument bas proved very useful in a subperitoneal pedunculated growth of the uterus, and in two cases of uterine epithelioma. In a highly vascular growth of the rectum, in a female, it was found highly efficient in controlling the severe hremorrhage which ensued after the growth had been trans-

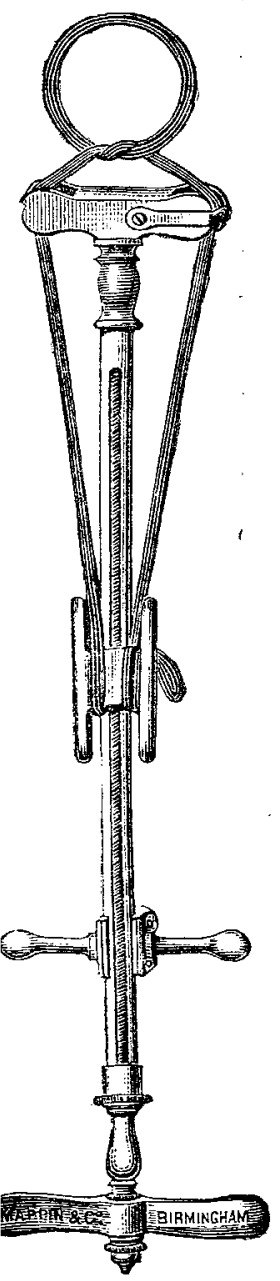
fixed and tied in two portions. The instrument was made for me by Messra. Mappin and Co., surgical instrument manufacturers, New-street, Birmingham. Birmingham. 